\title{
Extent and symmetry of post-juvenile moult as predictors of future performance in Greenfinch Carduelis chloris
}

\author{
Piotr Minias • Tomasz Iciek
}

Received: 21 August 2012/Revised: 6 September 2012/Accepted: 6 November 2012/Published online: 22 November 2012

(C) The Author(s) 2012. This article is published with open access at Springerlink.com

\begin{abstract}
The extent of post-juvenile moult in passerines is highly variable, but the causes and consequences of such variability remain poorly understood. We tested the hypothesis that the extent and symmetry of post-juvenile moult of Greenfinches Carduelis chloris may be used as reliable predictors of their winter/spring body condition. We found a quadratic relationship between moult extent and the body mass/wing length ratio during the winter/ spring period. We also found that Greenfinches with higher degree of moult symmetry had greater winter/spring fat reserves. Our results suggest that the extent and symmetry of post-juvenile moult may be considered as adaptive traits with certain fitness consequences.
\end{abstract}

Keywords Body condition - Greenfinch · Moult asymmetry $\cdot$ Post-juvenile moult

\section{Zusammenfassung}

Ausmaß und Symmetrie der Postjuvenilmauser als Hinweis auf zukünftige Leistungsfähigkeit beim Grünfink (Carduelis chloris)

Das Ausmaß der Postjuvenilmauser bei Singvögeln ist hoch variabel, aber die Ursachen und Konsequenzen solcher Variabilität sind noch immer schlecht untersucht. Wir

Communicated by F. Bairlein.

P. Minias $(\bowtie)$

Department of Teacher Training and Biodiversity Studies, University of Łódź, Banacha 1/3, 90-237 Lodz, Poland

e-mail: pminias@biol.uni.lodz.pl

T. Iciek

Rojna 37/21, 91-134 Lodz, Poland untersuchten die Hypothese, dass das Ausmaß und die Symmetrie der Postjuvenilmauser bei Grünfinken als zuverlässiger Hinweis auf ihre körperliche Verfassung im Winter und Frühling genutzt werden kann. Wir fanden einen quadratischen Zusammenhang zwischen dem Ausmaß der Mauser und dem Verhältnis von Körpermasse und Flügellänge im folgenden Winter und Frühling. Wir fanden auch, dass Grünfinken mit einer größeren Mausersymmetrie größere Fettreserven im Winter und Frühling hatten. Unsere Ergebnisse deuten darauf hin, dass Ausmaß und Symmetrie der Postjuvenilmauser adaptive Anpassungen mit Konsequenzen für die spätere Fitness sind.

\section{Introduction}

In the majority of passerines, the extent of partial postjuvenile moult shows great intra-specific variation, ranging from no replacement of wing and tail feathers to almost entire or entire wing and tail feather replacement (Jenni and Winkler 1994). The extent of post-juvenile moult may be affected by several different life-history traits in passerines, the time of hatching being considered as one of the most important. There is strong empirical evidence that individuals hatched late in the season renew fewer feathers in comparison to their early-hatched conspecifics, as the time available for moulting is strictly limited, especially in migratory species (Bojarinova et al. 1999). Since the general body condition of fledglings frequently deteriorates over the course of a breeding season, reduction in the extent of post-juvenile moult by late-hatched individuals is usually attributed to an energetic constraint. Under such circumstances, moult extent should reflect the nutritional status of birds at the time of moulting, which is supported 
by the correlative studies on passerines (Senar et al. 1998). As a condition-dependent trait, moult extent was also suggested to correlate with the future performance of birds. Such relationship not necessarily must be of causal character, as it could be the low body condition during the postjuvenile moult, rather than moult extent itself, which may be responsible for the long-term fitness effects. However, at least two mechanisms were proposed to explain direct positive effects of extensive post-juvenile moult on the future performance in birds. Firstly, the overall structural quality of the plumage is likely to increase with the number of replaced feathers, which may affect flight performance (Jenni and Winkler 1994). Secondly, an extensive moult reduces the juvenile plumage characters, which increases the dominance status and competitive abilities of individuals. Under this hypothesis, yearlings with higher number of replaced feathers could attain better access to food during the first winter, which would result in their better physical condition and higher survival (Gosler 1994). Apart from the moult extent, also asymmetry in the renewal of the left- and right-side feather tracts was proposed as a valid predictor of performance in birds. Degree of fluctuating asymmetry reflects developmental stability and, thus, may have profound fitness consequences (Møller 1999). The studies on the consequences of moult asymmetry are lacking in passerines, however partial moult asymmetry was demonstrated to correlate negatively with survival probability in Ural Owls Strix uralensis (Brommer et al. 2003). The aim of this study was to investigate whether the extent and asymmetry of the post-juvenile moult may be used as predictors of winter body condition, an important determinant of over-winter survival, in a migratory passerine, Greenfinch Carduelis chloris. Specifically, we predicted that individuals with more extensive and symmetrical moult would be in a better condition or would accumulate higher fat loads during winter.

\section{Methods}

In total, 513 juvenile Greenfinches were caught at baited feeders in the suburban area of Łódź $\left(51^{\circ} 49^{\prime} \mathrm{N}, 19^{\circ} 22 \mathrm{E}\right)$, central Poland, between the beginning of January and the end of April 2009. All captured individuals were sexed according to Svensson (1992), ringed, and measured at the time of catching. We measured wing length with a stopped ruler to the nearest $1 \mathrm{~mm}$ and body mass with an electronic balance to the nearest $0.1 \mathrm{~g}$. Body condition of Greenfinches was calculated as the ratio of body mass and wing length, which is a common practice in avian studies (e.g., Izhaki and Maitav 1998). Visible fat deposits in the furculum region and over the abdomen were assessed by one of the authors (TI) according to $0-5$ score scale developed for passerines (Krementz and Pendleton 1990). At the time of capture none of the first-year Greenfinches was actively moulting, which indicated that all birds had already completed their post-juvenile moult. Such timing of moult conclusion (by the end of December) was consistent with data from other European populations of this species (Newton 1968). The extent of post-juvenile moult was quantified in flight feathers (primaries, secondaries, tertials) and wing coverts (primary and greater coverts) of both wings, as well as in rectrices. We expressed the extent of moult as the total number of moulted feathers (moult index). The position-specific degree of moult asymmetry was calculated as a sum of all asymmetrically moulted feather positions in the wings and tail (moult asymmetry index). Since the level of partial-moult asymmetry is likely to depend on the number of moulted feathers (Brommer et al. 2003), we corrected the measure of moult asymmetry for the extent of moult. For this purpose, we calculated residuals of moult asymmetry index against the index of moult, according to the following regression equation: $\mathrm{N}_{\text {asym }}=0.073 \times \mathrm{N}_{\text {total }}-0.196\left(R^{2}=0.27, P<0.001\right)$, where $\mathrm{N}_{\text {asym }}$-number of asymmetrically moulted feather positions, $\mathrm{N}_{\text {total }}$-total number of moulted feathers. To improve normality residuals of moult asymmetry were logtransformed prior to analysis.

We used a $t$ test to check for sex-differences in moult index and moult asymmetry index. Effects of moult extent and moult asymmetry on body condition were analysed with the General Linear Models. The squared effect of both indexes were additionally entered in the models to check for the quadratic character of the relationships. The effect of sex was added as a fixed factor and date of capture was included as a covariate in the starting model. We used the stepwise methods of backward removal to select for the significant effects. Character of significant relationships was assessed with $\beta$ coefficients. We also used ANOVA to check for the variation in the extent and asymmetry of moult between birds with different fat scores attained during winter/spring period. The prediction that individuals with higher fat loads would show more extensive and symmetrical moult was tested with the trend analysis.

\section{Results}

The extent of post-juvenile moult in wing and tail feather tracts of captured Greenfinches was characterized in Table 1. There were sex-differences in the moult extent, as the index of moult was significantly higher in males when compared with females $(16.78 \pm 0.55$ vs. $14.04 \pm 0.63$; $t=3.31, d f=511, P<0.001)$. We found that after accounting for the date of capture $\left(F_{1,508}=19.12\right.$, $P<0.001)$, and $\operatorname{sex}\left(F_{1,508}=10.70, P=0.001\right)$, body 
condition was significantly related with the squared effect of moult index $\left(F_{1,508}=4.87, P=0.028\right)$, which indicated the quadratic character of the relationship. A higher extent of post-juvenile moult was associated with higher body condition during the winter/spring season, as was demonstrated by the positive $\beta$ coefficient of the squared moult index effect $\left(\beta=0.005 \times 10^{-3} \pm 0.002 \times 10^{-3}\right.$, Fig. 1). There was no significant effect of moult asymmetry on winter/spring body condition in Greenfinches, so it was excluded from the final model $(P=0.95)$.

Asymmetry in post-juvenile moult was recorded in $49.0 \%$ of birds. On average, Greenfinches moulted asymmetrically $0.93 \pm 0.06$ feather per bird $(N=513)$. There were no sex-differences in moult asymmetry of captured Greenfinches $(t=0.77, d f=511, P=0.44)$. We found higher level of post-juvenile moult asymmetry in birds with lower amounts of fat loads accumulated during winter/spring period $\left(F_{4,508}=3.08, \quad P=0.016\right.$, trend analysis: $\beta=-0.37 \pm 0.16, P=0.022$, Fig. 2 ). In contrast, there was no significant variation in moult index among birds with different winter/spring fat scores $\left(F_{4,508}=1.40, P=0.23\right)$.

\section{Discussion}

In this study we confirmed the hypothesis that both the extent and asymmetry of post-juvenile moult may be considered as valid predictors of winter body condition in Greenfinches. The relationship between post-juvenile moult extent and future performance in passerines was firstly suggested by Gosler (1991), who found that the moult extent of Great Tits Parus major correlated positively with the size of their pectoral muscles during winter. The mass of pectoral muscles, contributing to over $25 \%$ of the total body mass in flying birds, was proved to reliably indicate the protein reserves in different avian taxa (e.g., Davidson et al. 1986). In consequence, varying degrees of protein stress during moult were proposed to determine the

Table 1 The extent of post-juvenile moult in wing and tail feather tracts of Greenfinch $(\mathrm{N}=513)$

\begin{tabular}{lllcc}
\hline Feather tract & Range & Mean & \% all & \% some \\
\hline Primaries & $0-7$ & 0.09 & 0 & 4.5 \\
Secondaries & $0-6$ & 0.07 & 0.4 & 3.5 \\
Tertials & $0-3$ & 0.86 & 11.9 & 39.5 \\
Greater coverts & $0-9$ & 7.38 & 49.6 & 99.6 \\
Primary coverts & $0-7$ & 0.05 & 0 & 1.2 \\
Rectrices & $0-12$ & 2.05 & 7.6 & 44.2 \\
\hline
\end{tabular}

'\% all' stands for the proportion of birds which moulted all feathers from a given tract, ' $\%$ some' stands for the proportion of birds which moulted at least one feather from a given tract

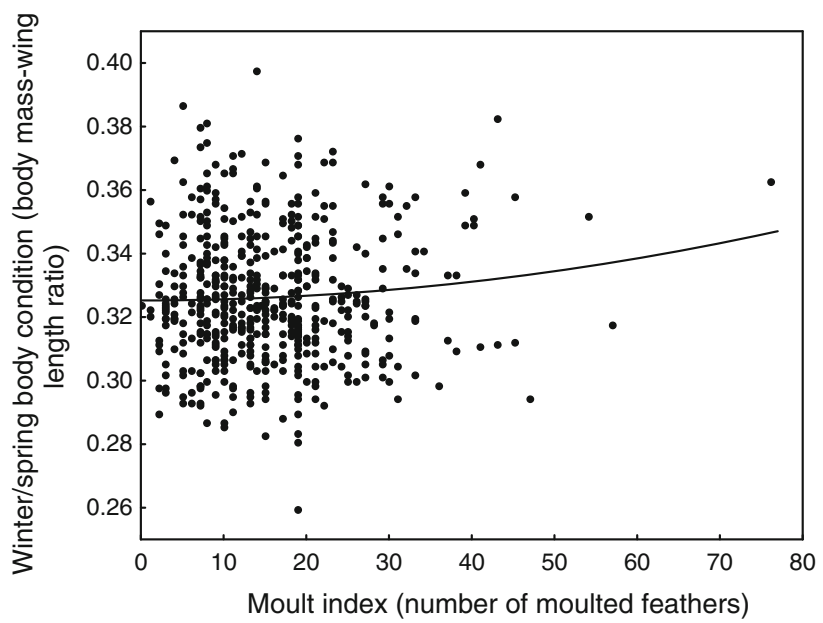

Fig. 1 The relationship between the extent of post-juvenile moult (moult index) and winter/spring body condition of Greenfinches captured in Łódź, central Poland

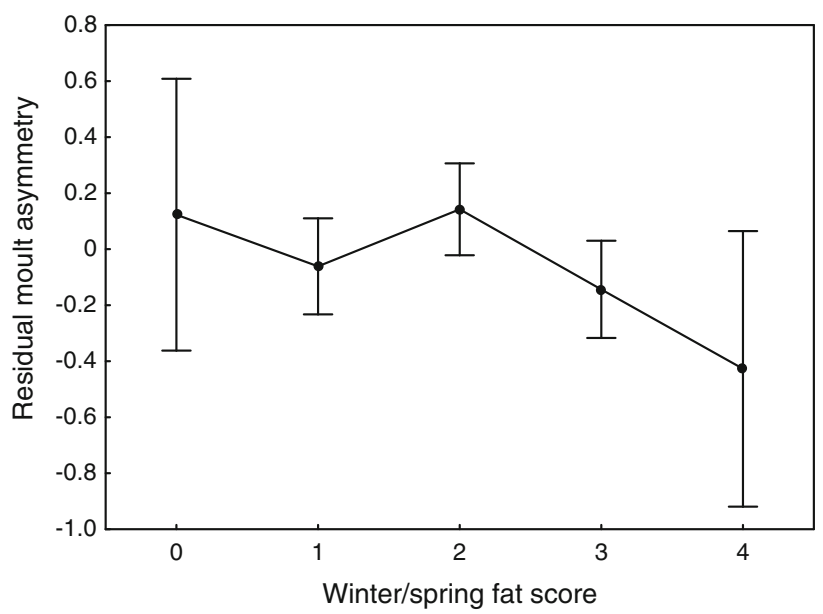

Fig. 2 Asymmetry of post-juvenile moult corrected for the number of replaced feathers in Greenfinches with different winter/spring fat scores (means $\pm 1.96 * \mathrm{SE}$ )

extent of post-juvenile moult in this species (Gosler 1991). A similar relationship was found in male first-year Siskins Carduelis spinus, as their body masses correlated with the extent of moult shortly after its completion (Senar et al. 1998). However, the relationship reversed in late winter, which was attributed to the intensified aggression of adults towards more adult-looking yearlings. A similar conclusion was reached by López et al. (2005), who found raised heterophile/lymphocyte $(\mathrm{H} / \mathrm{L})$ ratios during winter in White Wagtails Motacilla alba after extensive post-juvenile moult. Since stress increases the number of heterophils circulating in the blood and simultaneously reduces the number of lymphocytes, the H/L reflects the strength of different stressors acting on the organism. The $\mathrm{H} / \mathrm{L}$ ratio is especially valid as an indicator of social stress (Gross and Siegel 1983), which seems to confirm high adult 
intolerance towards first-year Wagtails with more adultlike characters in plumage. However, adult aggressiveness towards young birds may be of much less importance in Greenfinches, as experimental studies on this species demonstrated that yearlings tend to be more dominant than adults (Arenas et al. 2003). In such cases, extensive moult may appear adaptive in terms of plumage quality during the winter time.

In contrast, asymmetrical moulting confers certain energetic costs to flying birds, especially when remiges are moulted. Asymmetries in flight-feathers were demonstrated to negatively affect turning performance and asymmetric lengths of rectrices to reduce general flight manoeuvrability (Thomas 1993). For these reasons, there should be a selective force on the moult symmetry resulting in birds of higher intrinsic quality moulting in a more symmetrical manner. Nevertheless, the costs of asymmetrical feather replacement prevail at the time of moulting and should not persist after the conclusion of moult. Thus, the relationship between the asymmetry of post-juvenile moult and winter/ spring fat reserves seems to be purely correlative, as highquality individuals are also likely to be in a better physical condition during the periods of low food availability. From this point of view, the lack of significant relationship between moult asymmetry and body mass/wing length ratio is difficult to explain. However, we cannot exclude that an increased resting metabolic rate potentially associated with high degree of developmental instability (Møller 1997) could be reflected more in the quantity of fat loads rather than in the size-adjusted body mass.

Acknowledgments We thank all the participants of the fieldwork, especially Tomasz Janiszewski. We are also grateful for two anonymous referees who commented on the earlier draft of the paper.

Open Access This article is distributed under the terms of the Creative Commons Attribution License which permits any use, distribution, and reproduction in any medium, provided the original author(s) and the source are credited.

\section{References}

Arenas M, Senar JC, Domínguez J (2003) Social environment affects correlates of dominance status in the greenfinch Carduelis chloris. Etología 11:15-21

Bojarinova JG, Lehikoinen E, Eeva T (1999) Dependence of postjuvenile moult on hatching date, condition and sex in the Great Tit. J Avian Biol 30:437-446

Brommer JE, Pihlajamäki O, Kolunen H, Pietiäinen H (2003) Lifehistory consequences of partial-moult asymmetry. J Anim Ecol 72:1057-1063

Davidson NC, Evans PR, Uttley JT (1986) Geographical variation of protein reserves in birds: the pectoral muscle mass of Dunlins Calidris alpina in winter. J Zool (Lond) 208:125-133

Gosler AG (1991) On the use of greater covert moult and pectoral muscle as measures of condition in passerines with data for the Great Tit Parus major. Bird Study 38:1-9

Gosler AG (1994) Mass-change during moult in the Great Tit Parus major. Bird Study 41:146-154

Gross WB, Siegel HS (1983) Evaluation of heterophil/lymphocyte ratio as a measure of stress in chickens. Avian Dis 27:972-979

Izhaki I, Maitav A (1998) Blackcaps Sylvia atricapilla stopping over at the desert edge; inter- and intra-sexual differences in spring and autumn migration. Ibis 140:234-243

Jenni L, Winkler R (1994) Moult and ageing of European passerines. Academic Press, London

Krementz DG, Pendleton GW (1990) Fat scoring: sources of variability. Condor 95:500-507

López G, Figuerola J, Varo N, Soriguer R (2005) White Wagtails Motacilla alba showing extensive post-juvenile moult are more stressed. Ardea 93:237-244

Møller AP (1997) Development stability and fitness: a review. Am Nat 149:916-932

Møller AP (1999) Asymmetry as predictor of growth, fecundity and survival. Ecol Lett 2:149-156

Newton I (1968) The moulting seasons of some finches and buntings. Bird Study 15:84-92

Senar JC, Copete JL, Martín AJ (1998) Behavioural and morphological correlates of variation in the extent of post-juvenile moult in the Siskin Carduelis spinus. Ibis 140:661-669

Svensson L (1992) Identification guide to European passerines. Stockholm, Märstatryck

Thomas A (1993) The aerodynamic cost of asymmetry in the wings and tails of birds: asymmetric birds can't fly around tight corners. Proc R Soc Lond B 254:849-854 